ISSN : 2615-1995, E-ISSN : 2615-0654

J. Madani., Vol. 4, No. 1, Maret 2021 (70 - 86)

(C)2018 Lembaga Kajian Demokrasi

\title{
COVID-19 dan Kebijakan dalam Menyikapi Resesi Ekonomi: Studi Kasus Indonesia, Filipina, dan Singapura
}

\author{
Shanti Darmastuti \\ Fakultas Ilmu Sosial dan Ilmu Politik, Universitas Pembangunan Nasional Veteran Jakarta \\ shanti.darmastuti@upnvj.ac.id \\ Mansur Juned \\ Fakultas Ilmu Sosial dan Ilmu Politik, Universitas Pembangunan Nasional Veteran Jakarta \\ mansurjuned@upnvj.ac.id \\ Fauzan Anggoro Susanto \\ Fakultas Ilmu Sosial dan Ilmu Politik, Universitas Pembangunan Nasional Veteran Jakarta \\ fauzans@upnvj.ac.id

\section{Rachmasari Nur Al-Husin} \\ Fakultas Ilmu Sosial dan Ilmu Politik, Universitas Pembangunan Nasional Veteran Jakarta \\ rachmasarinah@upnvj.ac.id
}

\begin{abstract}
Abstrak
Tujuan penelitian ini adalah untuk memberikan gambaran terhadap kondisi ekonomi yang dialami oleh beberapa negara seperti Indonesia, Filipina, dan Singapura akibat dari COVID-19. Melalui metode studi literatur, artikel ini melihat kondisi ekonomi serta bentuk kebijakan yang diambil oleh Indonesia, Filipina, dan Singapura dalam menyikapi ancaman resesi ekonomi. Tiga negara ini diambil sebagi fokus studi mengingat kasus COVID-19 terbanyak di kawasan Asia Tenggara terdapat di tiga negara ini. Hasil penelitian menunjukkan bahwa kasus COVID-19 memberikan dampakyang cukup signifikan bagi setiap negara. Banyak sektor yang terdampak dari adanya kasus ini. Kebijakan untuk memotong rantai perluasan dari Pandemi ini melalui karantina wilayah maupun pembatasan mobilitas orang memberikan dampak yang cukup besar di sektor ekonomi. Penurunan aktivitas ekonomi telah memberikan dampak bagi penurunan distribusi pendapatan, penurunan konsumsi domestik sampai dengan peningkatan pengangguran. Masalah-masalah ini apabila terjadi dalam jangka panjang dikhawatirkan akan menimbulkan ancaman resesi ekonomi bagi satu negara. Pada resesi ekonomi, negara biasanya akan mengambil bentuk kebijakan fiskal maupun moneter untuk melakukan pemulihan ekonomi ataupun mencegah terjadinya resesi yang lebih dalam. Simpulan dari penelitian ini adalah bahwa ancaman resesi ekonomi pada masa COVID-19 menjadi sangat kompleks dikarenakan satu negara dihadapkan pada masalah krisis kesehatan yang memberikan efek domino bagi sektor lainnya. Oleh karena itu, pemulihan ekonomi pada masa COVID-19 perlu memperhatikan upaya pengurangan perluasan virus sehingga krisis berkelanjutan baik dalam bidang ekonomi maupun kesehatan tidak terjadi lebih luas.
\end{abstract}

Kata Kunci : COVID-19, Resesi, Ekonomi, Kebijakan, Indonesia, Filipina, Singapura 


\begin{abstract}
The purpose of this study is to provide an overview of the economic conditions in Indonesia, Philippines and Singapore after COVID-19. Through a literature study, this article looks at economic conditions and the forms of policies taken by Indonesia, Philippines, and Singapore in response to the threat of economic recession. These three countries were taken as the focus of the study considering that the most COVID-19 cases in the Southeast Asia are in these three countries. The result of this research shows that COVID-19 case has had a significant impact on every country. Many sectors are affected by this case. The policies made to prevent the spread of pandemic such as lockdowns and restrictions on the mobility of people have had a significant impact on the economic sector. The decline in economic activity has had an impact on reducing the distribution of income, decreasing domestic consumption and increasing unemployment. If these problems occur in the long term, chances are economic recession will come to these countries. In an economic recession, countries will usually take the form of fiscal and monetary policies to recover the economy or prevent a deeper recession. The conclusion of this research is the threat of an economic recession during the COVID-19 pandemic has become very complex because one country must face a health crisis that has a domino effect on other sectors. Therefore, economic recovery during the COVID-19 needs to pay attention toward the spread of the virus reduction so that the ongoing crisis, both in the economic and health sectors, does not become more severe.
\end{abstract}

Keywords : COVID-19, Recession, Economy, Policy, Indonesia, Philippines, Singapore

\section{PENDAHULUAN}

Peningkatan kasus COVID-19 menjadi perhatian setiap negara. Setiap negara berupaya menerapkan kebijakan untuk memotong rantai penularan dari virus ini. Pembatasan aktivitas seperti transportasi, karantina wilayah, pembatasan mobilitas orang menjadi contoh dari kebijakan yang diambil untuk memotong rantai perluasan COVID-19. Pembatasan yang dilakukan ternyata juga memberikan dampak terhadap aktivitas ekonomi yang kemudian juga berdampak pada perekonomian negara.

Kasus COVID-19 menjadi perhatian setiap negara saat ini dikarenakan kasus ini tidak hanya berdampak pada krisis kesehatan, namun dalam perkembangannya kasus ini membawa dampak ekonomi yang berbeda antara satu dengan negara lain. Sehubungan dengan dampak ekonomi, secara global kasus ini akan memberikan dampak terhadap pertumbuhan ekonomi. Diperkirakan bahwa secara global akan terjadi kontraksi PDB sebesar 5,2 persen. Persoalan ini memberikan dampak yang lebih jauh terhadap penurunan investasi, masalah sosial seperti meningkatnya angka pengangguran. Hal ini tentu saja tidak mudah bagi setiap negara untuk mengambil kebijakan dalam mengatasi krisis kesehatan dan kebijakan pemulihan ekonomi dalam waktu bersamaan. Negara berkembang, misalnya, akan dihadapkan dengan sejumlah tantangan seperti penurunan kinerja perdagangan, infrastruktur kesehatan yang membutuhkan dukungan besar dalam menyikapi kasus COVID-19, penurunan aliran modal bahkan peningkatan utang (World Bank, 2020).

Persoalan ekonomi yang muncul saat ini mengingatkan pada krisis global yang pernah terjadi di tahun 2009. Meskipun penyebab dari krisis ini berbeda, namun pada saat itu negara juga dihadapkan dengan tantangan untuk mengambil beberapa langkah kebijakan dalam menghadapi persoalan ekonomi yang terjadi. Sebagaimana yang telah kita ketahui bahwa krisis pada saat itu terjadi karena adanya krisis perbankan yang disebabkan oleh gagal bayar cicilan rumah terhadap bank.

Permasalahan tidak berhenti di sini, krisis yang terjadi juga diwarnai dengan meningkatnya pengangguran maupun turunnya pendapatan bisnis. Sementara permasalahan ekonomi yang muncul pada saat Pandemi sekarang disebabkan oleh adanya kebijakan lockdown serta pembatasan kegiatan yang dilakukan oleh beberapa negara, hal ini ternyata memberikan dampak besar bagi penurunan aktivitas ekonomi.

Setiap negara memiliki dampak yang beragam tergantung dari struktur ekonomi di setiap negara. Sektor-sektor seperti perdagangan, pariwisata, transportasi menjadi contoh beberapa sektor yang sangat terdampak akibat dari kasus COVID-19. 
Persoalan ini memberikan dampak bagi orangorang yang bekerja pada sektor-sektor ini. Tidak hanya permasalahan distribusi pendapatan, tetapi juga banyak orang yang kehilangan pekerjaan akibat Pandemi ini. Hal ini tentu saja menimbulkan kontraksi terhadap pertumbuhan ekonomi negara (United Nations, 2020).

Menurut International Monetary Fund dan World Bank sesuai prediksinya bahwa pada tahun 2020 akan terjadi resesi ekonomi global. Menurut kedua lembaga tersebut secara garis besar pertumbuhan ekonomi global akan menurun hingga negatif $2,8 \%$. Padahal jika ditarik ke belakang, kedua lembaga tersebut sebelumnya memprediksi bahwa pertumbuhan ekonomi akan meningkat sebanyak 3\%. Namun terjadi suatu hal yang tidak disangka yaitu Pandemi COVID-19, menyebabkan perubahan yang sangat berbeda. Suatu hal yang belum pernah terjadi sebelumnya, membuat gejolak luar biasa bagi seluruh negara (Nasution, Erlina, \& Muda, 2020).

Kebijakan pembatasan kegiatan untuk memotong rantai COVID-19 memberikan dampak ekonomi yang beragam bagi setiap negara. Dampak ekonomi yang terjadi seperti penurunan aktivitas ekonomi, yang kemudian berdampak pada penurunan distribusi pendapatan serta peningkatan pengangguran. Penurunan yang tajam terhadap hal-hal tersebut dikhawatirkan akan mengakibatkan resesi ekonomi. Kondisi tersebut yang saat ini menjadi perhatian setiap negara dengan membuat serangkaian kebijakan untuk menyikapinya.

COVID-19 menimbulkan kegoncangan bagi seluruh dunia dan pada berbagai sektor terlebih ekonomi. Hal ini juga diiringi dengan jumlah kasus yang terus meningkat dan angka kematian yang tinggi. Untuk dapat menanggulangi permasalahan ini tentu setiap negara telah menyiapkan kebijakan tertentu. Baik kebijakan fiskal maupun moneter semua sudah dipersiapkan, namun memang ada perbedaan antara tiap negara (Barua, 2020).

Bicara mengenai resesi ekonomi, peningkatan pengangguran dan penurunan pendapatan menjadi salah satu aspek pemicu terjadinya resesi ekonomi, hal ini bisa terjadi dikarenakan dalam jangka panjang pengangguran dan penurunan pendapatan akan berakibat pada penurunan kesejahteraan yang besar. Dampak besar yang terjadi dari resesi ekonomi yang berkepanjangan akan mengakibatkan penurunan kesehatan mental pada populasi satu negara. Penurunan kesehatan mental ini merupakan cerminan dari masyarakat yang menghadapi kesulitan distribusi kesejahteraan secara ekstrim (Boyce, Delaney, \& Wood, 2018).

Empat resesi global telah mewarnai ekonomi dunia sejak tahun 1950 diantaranya resesi yang terjadi pada tahun 1975, 1982, 1991, dan 2009. Kontraksi dalam PDB global perkapita tahunan riil mewarnai dari resesi yang terjadi. Gangguan ekonomi dan keuangan juga mewarnai resesi tersebut. Sejauh ini resesi global yang terjadi pada tahun 2009 menjadi resesi yang cukup dalam bagi negara-negara maju. Sementara pasar negara berkembang dan negara berkembang berhasil mengatasi resesi global 2009 dengan relatif baik (Kose, Sugawara, \& Terrones, 2020).

COVID-19 adalah permasalahan kesehatan, lantas bagaimana ia dapat berubah menjadi permasalahan ekonomi? Jawabannya yaitu karena lockdown menyebabkan penutupan beberapa sektor krusial. Bahkan beberapa perusahaan mengalami kebangkrutan dan terpaksa menutup bisnis, membuat banyak permasalahan baru muncul (Ozili \& Arun, 2020).

Potensi resesi ekonomi yang terjadi di era COVID-19 merupakan bentuk resesi yang diawali dari krisis kesehatan yang mengharuskan setiap negara untuk mengambil kebijakan yang lebih responsif seperti karantina wilayah dan sebagainya. Krisis kesehatan ini selanjutnya memberikan dampak penurunan aktivitas ekonomi yang diwarnai dengan sejumlah persoalan yang memiliki karakteristik seperti pada yang terjadi dalam sebuah resesi ekonomi.

Dalam hal ini apabila persoalan ekonomi yang muncul akibat Pandemi ini berlangsung berkepanjangan, maka resesi ekonomi dikhawatirkan akan terjadi. Artikel ini berupaya untuk melihat dampak dari COVID-19 terhadap ancaman terjadinya resesi ekonomi di negaranegara ASEAN khususnya Indonesia, Filipina, dan Singapura. Selanjutnya, artikel ini juga akan memberikan gambaran terhadap kebijakan yang diambil oleh negara-negara tersebut dalam menyikapi ancaman resesi ekonomi yang terjadi akibat dari COVID-19.

\section{METODE}

Artikel ini menggunakan studi literatur dalam melihat kebijakan negara Indonesia, Filipina, dan Singapura dalam menyikapi ancaman resesi ekonomi akibat COVID-19. Tiga negara ini diambil sebagai kasus dalam artikel ini 
mengingat kasus positif terbesar di negara-negara ASEAN ada di tiga negara tersebut. Penjelasan dalam artikel ini mencakup beberapa bagian yang diawali dengan gambaran kasus COVID-19, dilanjutkan dengan ancaman resesi ekonomi serta kebijakan yang diambil dalam menyikapi resesi ekonomi. Studi literatur diperoleh dari buku, artikel jurnal maupun artikel internet yang membahas persoalan mengenai COVID-19 dan dampak ekonomi serta kebijakan yang diambil oleh setiap negara.

\section{HASIL}

\section{Gambaran Kasus COVID-19 di Asia Tenggara}

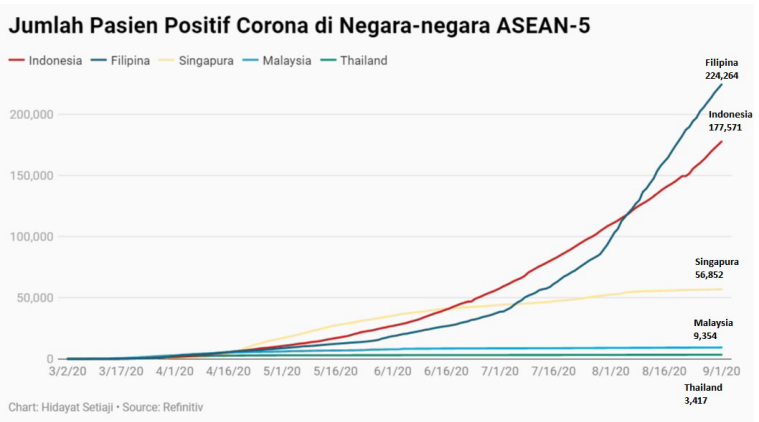

Gambar 1. Jumlah Pasien Positif Corona di Negara-negara ASEAN-5

Sumber: CNBC Indonesia, 2020

Berdasarkan Gambar 1 dapat dilihat bahwa negara ASEAN yang mengkonfirmasi jumlah pasien COVID-19 terbanyak meliputi Thailand, Malaysia, Singapura, Indonesia, dan Filipina. Negara ASEAN yang pertama yang tersebar virus COVID-19 yaitu di Thailand. Pada tanggal 13 Januari 2020, Menteri Kesehatan Thailand untuk pertama kalinya melaporkan pasien kasus positif COVID-19 di Thailand (Mahatma Chryshna, 2020). Seiring berjalannya waktu, hingga 1 September 2020, Filipina merupakan negara dengan jumlah pasien positif terbanyak di kawasan ASEAN yaitu mencapai angka 224,264 jiwa (CNBC Indonesia, 2020).

Kasus COVID-19 di Indonesia pertama kali diumumkan pada 2 Maret 2020 (Mahatma Chryshna, 2020). Pertambahan jumlah pasien positif COVID-19 di Indonesia pada bulan Maret dapat dikatakan cukup besar, karena bertambah sekitar seratus pasien setiap harinya hingga berjumlah 1,677 jiwa pada 1 April 2020 (TribunNews, 2020). Jumlah pasien positif COVID-19 di Indonesia ini terus mengalami kenaikan yang signifikan, pada 1 Agustus 2020 jumlahnya sebesar 109,936 jiwa. Satu bulan kemudian, yaitu pada 1 September 2020, jumlah pasien positif COVID-19 di Indonesia mencapai angka 177,571 jiwa. Jumlah ini menempatkan Indonesia di urutan kedua sebagai negara dengan pasien COVID-19 terbanyak di kawasan ASEAN.

Singapura mengumumkan kasus COVID-19 pertama kali di negaranya pada tanggal 23 Januari 2020 (Mahatma, 2020). Pada 1 Agustus 2020, jumlah pasien positif bertambah hingga mencapai angka 52,513 jiwa. Kemudian pada 1 September 2020 jumlah pasien positif mengalami kenaikan mencapai angka 56,852 jiwa. Jika dibandingkan dengan jumlah kenaikan pada bulan-bulan sebelumnya, kenaikan jumlah pasien positif di Singapura pada bulan Agustus hingga 1 September 2020 merupakan jumlah kenaikan yang paling kecil. Singapura menempati urutan ketiga sebagai negara dengan pasien COVID-19.

Sementara kasus COVID-19 pertama kali di Malaysia dikonfirmasi pada tanggal 25 Januari 2020. Pada 1 Agustus 2020, jumlah pasien positif COVID-19 sebesar 8.985 jiwa. Lalu pada 1 September 2020, pasien positif COVID-19 di Malaysia berjumlah 9,354 jiwa. Jika dibandingkan dengan bulan-bulan sebelumnya, dalam 3 bulan terakhir pertambahan pasien positif di Malaysia terus mengalami penurunan. Malaysia berada pada urutan keempat dengan pasien COVID-19 terbanyak di kawasan ASEAN.

Thailand sebagai negara pertama yang mengkonfirmasi kasus COVID-19 pada 1 Agustus 2020, jumlah pasien positif mencapai angka 3,312 jiwa. Pada 1 September 2020, jumlah pasien positif bertambah sebanyak 105 jiwa menjadi 3,417 jiwa. Angka ini menempatkan Thailand dalam urutan kelima sebagai negara dengan pasien COVID-19 terbanyak di kawasan ASEAN (CNBC Indonesia, 2020).

Sementara data resmi yang dikeluarkan oleh ASEAN yang dilaporkan per 7 Agustus 2020, mencatat 306.644 yang terkonfirmasi positif COVID-19 dengan total jumlah angka kematian sebanyak 7.900. Pada tabel 1 menunjukkan, kasus COVID-19 tertinggi yang terkonfirmasi adalah Filipina, dengan total 119.460, melebihi total kasus di Indonesia yang mencatat 118.753. Tingginya kasus di Filipina dikarenakan pelonggaran langkah-langkah karantina dan pembukaan ekonomi secara bertahap. Indonesia terus mencatat angka kematian tertinggi dengan jumlah 5.521, angka ini termasuk tinggi dari rata- 
rata global (ASEAN REPORT, 2020).

Tabel 1. Jumlah Kasus Positif COVID-19 per 7 Agustus 2020

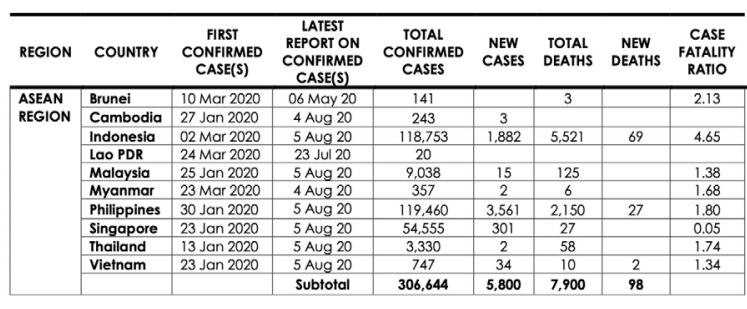

Sumber: asean.org, 2020

Sehubungan dengan permasalahan ini, kasus COVID-19 juga dilihat dari sisi keamanan kesehatan satu negara. Menurut Yani, dkk (2017) dalam buku Pengantar Studi Keamanan memberikan pemahaman bahwa definisi keamanan mempunyai arti yang umum dan sangat beragam, sehingga tergantung dengan kata yang mengikutinya. Dilihat pada tabel 2, maka kasus COVID-19 dapat dibahas dari berbagai analisis. Namun, saat ini penulis akan menganalisis pada kategori keamanan bagi manusia atau insani di level analisis individu. Sesuai dengan laporan dari Human Development Report di tahun 1994 yang dikeluarkan oleh organisasi internasional UNDP, maka definisi dari konsep keamanan manusia atau insani adalah keamanan bagi manusia dari ketidakamanan atau ancamanancaman yang kronis seperti penyakit, tindakan represif, kelaparan, tindakan perdagangan manusia, genosida, dan lainnya (United Nations Development Program, 1994).

Tabel 2. Kategori Keamanan menurut Level

\begin{tabular}{cll}
\hline No & \multicolumn{1}{c}{ Kategori } & \multicolumn{1}{c}{ Level } \\
\hline 1 & Keamanan Internasional & Level Dunia \\
& dan Keamanan Global & \\
2 & Keamanan Nasional & Level Negara \\
3 & Keamanan Publik & Level Masyarakat \\
4 & Keamanan Manusia atau & Level Individu \\
& Keamanan Insani & \\
\hline
\end{tabular}

Sumber: Yani, dkk, 2017

Sehubungan dengan kondisi ini, kasus COVID-19 tidak hanya dapat dilihat dari aspek kesehatan maupun keamanan manusia saja tetapi juga dapat dilihat dari sisi sosial maupun ekonomi. Nicola, et.al (2020) menjelaskan bahwa COVID-19 telah memberikan dampak yang besar bagi sistem kesehatan global dan lebih lanjut memberikan dampak bagi setiap aspek kehidupan manusia. Pemerintah di beberapa negara telah mengambil serangkaian kebijakan untuk menurunkan kasus COVID-19. Penutupan perbatasan, pembatasan perjalanan, dan kebijakan karantina yang dilakukan di beberapa negara memunculkan kekhawatiran akan terjadinya krisis ekonomi dan resesi yang akan datang (Nicola, et al., 2020).

\section{COVID-19 dan Ancaman Resesi Ekonomi}

Dampak COVID-19 dirasakan pada banyak sektor krusial suatu negara seperti ekonomi, sosial, politik, dan kesehatan. Terutama pada sektor ekonomi yang menyebabkan turunnya laju pertumbuhan perekonomian negara. Penurunan ini memunculkan timbulnya suatu ancaman serius bagi negara yaitu resesi ekonomi. Di antara negara-negara ASEAN setidaknya terdapat tiga negara yang mengalami ancaman resesi ekonomi cukup serius antara lain Indonesia, Filipina, dan Singapura. Mengingat Pandemi COVID-19 belum menemukan titik terang, maka ancaman resesi ekonomi tersebut diperkirakan masih berlanjut sampai pada waktu yang belum bisa diprediksi.

Bicara mengenai resesi ekonomi, terdapat beberapa sumber dari terjadinya resesi ekonomi. Misalnya salah satu penyebab terjadinya resesi adalah terjadinya perubahan harga input yang digunakan dalam memproduksi barang dan jasa. Tentu saja perubahan harga yang menyebabkan terjadinya resesi adalah perubahan harga yang cukup tajam dibanding sebelumnya. Kenaikan harga minyak misalnya, dapat mengakibatkan kenaikan harga secara keseluruhan dan akan mengurangi permintaan. Di samping itu, kebijakan moneter atau fiskal yang kontraktif yang diterapkan oleh pemerintah untuk mengurangi inflasi juga dapat memicu resesi apabila digunakan secara berlebihan. Kebijakan yang digunakan berlebihan dapat menyebabkan penurunan permintaan barang dan jasa yang pada akhirnya mengakibatkan resesi.

Secara umum, beberapa karakteristik dari resesi ekonomi seperti: 1) Secara khusus resesi ekonomi dikaitkan dengan penurunan Produk Domestik Bruto (PDB) sebesar 2 persen, dan dalam kasus yang parah bisa mencapai 5 persen; 2) Terjadinya penurunan produksi industri dan investasi serta penurunan tingkat konsumsi yang besar juga dapat menjadi pemicu dari terjadinya resesi; 3) Penurunan tajam aktivitas perdagangan internasional seperti ekspor dan impor selama periode perlambatan ekonomi; dan 4) Peningkatan 
pengangguran, penurunan permintaan barang dan jasa, serta adanya gejolak di pasar keuangan juga menjadi pemicu terjadinya resesi ekonomi (Classens \& Kose, 2020).

Di Indonesia, Pandemi COVID-19 mengakibatkan perekonomian Indonesia mengalami kontraksi untuk pertama kalinya dalam dua dekade terakhir, padahal Indonesia merupakan salah satu negara ASEAN yang memiliki tingkat perekonomian cukup baik di kawasan Asia Tenggara. Kontraksi ekonomi ini juga mengakibatkan penurunan persentase ekonomi yang tajam, sehingga ancaman resesi ekonomi semakin mendekati perekonomian Indonesia (World Socialist Website, 2020).

Pertumbuhan ekonomi Indonesia mencapai $2,97 \%$ pada kuartal I 2020, setelahnya saat kuartal II, mengalami minus 3,1\%. Penurunan tersebut disebabkan karena mulai diberlakukannya Pembatasan Sosial Skala Besar (PSBB) sehingga banyak kegiatan ekonomi yang terhambat bahkan terhenti sementara. Kondisi ini semakin tidak baik apabila di kuartal III pertumbuhan ekonomi Indonesia hanya mencapai sekitar minus 2 hingga 0 persen, maka Indonesia dikhawatirkan akan benarbenar mengalami resesi ekonomi. Sebab salah satu indikator terjadinya resesi ialah mengalami minus selama dua kuartal berturut-turut.

Sehubungan dengan hal tersebut, sebenarnya sejak Juni 2020 lalu, beberapa sektor ekonomi sudah mulai kembali beroperasional meskipun tidak semaksimal sebelum adanya COVID-19. Akan tetapi kenyataannya belum cukup memulihkan pertumbuhan ekonomi negara, dengan demikian hal tersebut dapat berimbas pada kuartal III 2020. Ditambah lagi terdapat beberapa sektor ekonomi yang menjadi lebih terpuruk akibat COVID-19. Tentu ini menjadi ancaman serius bagi Indonesia karena bisa jadi mengakibatkan resesi dan banyak dampak buruk yang akan dihadapi terlebih kasus positif COVID-19 terus bertambah (CNN Indonesia, 2020).

Dalam hal pertumbuhan ekonomi, Indonesia lebih condong bergantung kepada tingkat konsumsi domestik. Akan tetapi hal tersebut tetap patut diantisipasi supaya Indonesia siap dengan segala kemungkinan buruk terutama ancaman resesi ekonomi. Kontraksi ekonomi di kuartal III 2020 bisa saja terjadi mengingat penerapan new normal belum memiliki dampak signifikan terhadap perkembangan ekonomi Indonesia. Apabila resesi ekonomi benar-benar terjadi, maka hal tersebut akan menjadi yang pertama sejak krisis 1998. Kalaupun resesi ekonomi ini akan terjadi, diperkirakan resesi yang akan dilalui oleh Indonesia tidak di seberat negara maju. Hal ini disebabkan karena Indonesia bukanlah negara yang bergantung dengan perdagangan internasional, tetapi bergantung pada kebutuhan domestik. Kebutuhan domestik Indonesia saat ini sudah kembali berjalan normal sejak adanya new normal, meskipun belum berdampak secara signifikan (Medcom.id, 2020).

Dari gambaran tersebut di atas dapat dilihat bahwa Indonesia dapat terancam mengalami resesi ekonomi apabila pada kuartal III 2020 tidak terdapat tanda kenaikan pertumbuhan ekonomi. Namun, ancaman tersebut dapat diminimalisir bahkan dihindari melalui kebijakan dan tindakan yang dilakukan oleh pemerintah. Terlebih Indonesia bukanlah negara yang ekonominya bergantung pada perdagangan internasional. Tetapi pemerintah Indonesia tetap harus mencari cara agar ancaman tersebut paling tidak dapat diminimalisir dan masyarakat memiliki keinginan untuk bekerjasama dengan pemerintah, dalam menangani Pandemi COVID-19 dan ancaman resesi ekonomi.

Persoalan ekonomi yang muncul akibat COVID-19 juga dialami Filipina yang memiliki kasus COVID-19 yang besar. Dampak COVID-19 yang sedang berlangsung diperkirakan akan berimbas pada pertumbuhan ekonomi pada tahun 2020. Pertumbuhan ekonomi ini tidak terlepas dari aktivitas perdagangan internasional dengan mitra dagangnya. China adalah mitra dagang utama Filipina yang menyumbang 18,8\% dari total perdagangan Filipina. Hal ini terlihat pada November 2019, 22,9\% ekspor Filipina adalah ke China. Di samping itu, impor Filipina juga berasal dari China sebesar $20 \%$ diikuti oleh Korea dan Jepang masing-masing sebesar 10\%. Kondisi COVID-19 diperkirakan dapat mempengaruhi aktivitas perdagangan yang sudah ada sebelumnya. Selain sektor perdagangan, sektor pariwisata juga menjadi salah satu sektor yang juga terdampak akibat Pandemi ini. Pada tahun 2018, sektor pariwisata menyumbang 12,7\% dari ekonomi Filipina. Bahkan lebih dari tujuh juta turis asing mengunjungi negara itu selama sepuluh bulan pertama di tahun 2019 (Pharmaceutical-technology.com, 2020). Dengan adanya kasus COVID-19 serta pembatasan mobilitas orang dan transportasi, maka kondisi pariwisata akan sangat terdampak. 
Bagi Filipina, kebijakan pembatasan mobilitas yang ketat tidak hanya telah melumpuhkan aktivitas ekonomi tetapi juga telah mengakibatkan penurunan besar pengeluaran ekonomi rumah tangga selama lima bulan terakhir yang merupakan salah satu penyumbang aset ekonomi. Hal ini memberikan dampak terhadap pertumbuhan ekonomi yang mengalami kontraksi dan mengalami resesi pada kuartal kedua. Selama ini ekonomi Filipina sangat didorong oleh kuatnya konsumsi rumah tangga, sehingga dengan adanya COVID-19 telah memberikan perubahan besar terhadap pengurangan konsumsi rumah tangga. Tidak hanya itu belanja rumah tangga yang didukung oleh aktivitas pengiriman uang dari pekerja Filipina di luar negeri juga mengalami penurunan. Pembatasan aktivitas selama COVID-19 telah melumpuhkan aktivitas konsumsi sebagai akibat dari peningkatan jumlah pengangguran sebesar $17,7 \%$ di bulan April 2020. Tentu saja hal ini berdampak besar pada kontraksi ekonomi Filipina dan pasar tenaga kerja yang membutuhkan waktu untuk pulih kembali (Think.ing.com, 2020).

Kontraksi ekonomi dapat dilihat dari penurunan PDB sebesar 16,5 persen di kuartal kedua. Penurunan ini tidak terlepas dari kebijakan pemerintah untuk memotong rantai penularan virus melalui kebijakan stay at home yang diterapkan cukup lama. Penurunan PDB ini dinilai merupakan penurunan terbesar dalam perekonomian Filipina.

Seperti yang telah dijelaskan sebelumnya kondisi penurunan ekonomi juga diperburuk oleh penurunan pengiriman uang oleh orang Filipina yang bekerja di luar negeri kepada keluarga mereka di Filipina. Hal ini terjadi karena pengiriman uang ini dinilai sebagai salah satu aktivitas pendorong belanja konsumen yang dapat memberikan kontribusi terhadap pertumbuhan ekonomi. Dalam lima bulan pertama pengiriman uang menurun sebesar 6,4 persen dibandingkan dengan periode yang sama di tahun lalu. Salah satu penyebab dari penurunan pengiriman uang ini adalah banyak pekerja Filipina yang kehilangan pekerjaan pada masa COVID-19. Pada kuartal kedua belanja konsumen juga mengalami penurunan sebesar 15,5 persen. Kondisi ini menjadi tantangan terbesar bagi sektor swasta dan publik dalam menghadapi upaya pemulihan ekonomi dan kesehatan (The Jakarta Post, 2020b).

Gambaran di atas memperlihatkan bahwa persoalan ekonomi yang muncul akibat COVID-19 memberikan kontribusi terhadap pertumbuhan ekonomi yang turun. Persoalan ekonomi ini dapat dilihat dari turunnya belanja konsumen yang merupakan akibat dari masalah sosial ekonomi yang lain seperti misalnya pengangguran. Hal ini memperlihatkan bawah kasus COVID-19 telah memunculkan persoalan yang sangat kompleks tidak hanya pada kesehatan tetapi juga berdampak pada sektor-sektor lainnya.

Sehubungan dengan resesi ekonomi ini, negara ASEAN lainnya yang berhadapan dengan persoalan ini adalah Singapura. Singapura merupakan negara ASEAN yang memiliki ekonomi dan fasilitas publik terbaik di kawasan Asia Tenggara, bahkan sudah termasuk dalam negara maju dengan penghasilan yang tinggi. Namun tetap saja Pandemi COVID-19 memberikan dampak buruk bagi Singapura terlebih pada sektor krusialnya.

Sama seperti negara lainnya, untuk menekan penyebaran COVID-19, Singapura juga memberlakukan sistem lockdown. Akan tetapi kenyataannya lockdown mengakibatkan dampak buruk bagi perekonomian negara, terbukti bahwa selama beberapa bulan belakangan ini muncul persoalan ancaman resesi ekonomi. Apalagi resesi ekonomi ini disebabkan oleh terpuruknya sektor ekonomi penting di Singapura. Beberapa hal yang mendorong terjadinya ancaman resesi ekonomi di Singapura dimulai dari kondisi internal negara sejak diberlakukan lockdown, yaitu banyaknya tenaga kerja yang terkena pemotongan gaji bahkan terkena PHK membuat pendapatan masyarakat menurun. Akibat dari itu, masyarakat cenderung lebih memilih untuk tinggal di dalam rumah kecuali jika ada sesuatu yang penting harus dikerjakan atau membeli kebutuhan sehari-hari.

Selain melindungi diri dari COVID-19, melakukan penghematan juga menjadi pendorong masyarakat untuk diam di rumah. Ketidakpastian ekonomi beriringan dengan jumlah pasien positif COVID-19 yang terus meningkat, membuat masyarakat lebih memprioritaskan simpanan keuangan untuk berjaga-jaga, maka uang yang beredar tidaklah banyak (Kim, Koh, \& Zhang, 2020).

Pada akhirnya saat ini Singapura secara resmi telah masuk ke dalam resesi ekonomi. Berdasarkan fakta, dapat dilihat bahwa Singapura telah mengalami minus pertumbuhan ekonomi selama dua kuartal berturut-turut. Dimana pada kuartal I 2020, pertumbuhan ekonomi mencapai minus $0,7 \%$, di kuartal II menjadi minus 
$41,2 \%$. Kenyataan bahwa Singapura mengalami resesi ekonomi akibat COVID-19 cukup mengguncangkan banyak pihak termasuk negara ASEAN. Sebab Singapura merupakan salah satu negara dengan ekonomi yang baik di ASEAN, bahkan sudah masuk ke dalam daftar negara maju di dunia. Merespon kondisi ini, persiapan dan koordinasi antar pemerintah Singapura dengan tenaga medis, lembaga keuangan, masyarakat, dan pihak berwenang lainnya dilakukan secara baik (CNBC Indonesia, 2020b).

Ancaman resesi ekonomi Singapura sudah mulai terasa sejak kasus pertama COVID-19 terkonfirmasi kemudian dilanjutkan pada kuartal II 2020, tepatnya saat mulai diberlakukan lockdown pada bulan April lalu. Pemberlakuan kebijakan diterapkan untuk meminimalisir rantai penyebaran COVID-19, namun terdapat sektor lain yang terdampak dari adanya kebijakan ini. Sektor tersebut ialah ekonomi yang sejak April berbagai kegiatan ekonomi berkurang dan terbatas. Meskipun di bulan Juni pemerintah sudah mulai melonggarkan aktivitas perekonomian, penurunan pertumbuhan ekonomi tetap terjadi.

Selama kebijakan lockdown diberlakukan, permintaan domestik menjadi menurun. Hal tersebut makin diperparah dengan permintaan global yang selaras menurun. Hal ini membuat aktivitas perdagangan internasional Singapura juga mengalami penurunan. Dengan demikian banyak sektor bisnis mengalami kerugian besar yang berimbas pada pertumbuhan ekonomi. Selain itu karena tidak adanya wisatawan asing yang datang, maka sektor pariwisata Singapura juga mengalami penurunan pemasukan.

Beberapa sektor ekonomi Singapura yang juga mengalami penyusutan di kuartal II antara lain: konstruksi yang mengalami minus sebesar 54,7\% dari tahun lalu karena kegiatan pembangunan diberhentikan sementara dan sektor jasa yang mengalami minus sebesar $13,6 \%$ dari tahun lalu dikarenakan banyaknya karyawan yang terpaksa diberhentikan. Angka tersebut cukup mendorong terjadinya resesi ekonomi di Singapura sebab sektor tersebut merupakan penopang perekonomian Singapura.

Perkiraan domestik bruto Singapura akan mengalami resesi teknis, yang artinya kontraksi pertumbuhan ekonomi Singapura dalam dua kuartal berturut-turut. Dan Singapura telah melaporkan di dalam tiga bulan berturut-turut pertumbuhan ekonomi Singapura telah mengalami penurunan $3,3 \%$ dan diperkirakan akan terus menurun di sepanjang tahun 2020. Penurunan pertumbuhan ekonomi Singapura disebabkan oleh penerapan lockdown yang dilakukan oleh pemerintah Singapura untuk mencegah penyebaran COVID-19. Dan penerapan lockdown ini memberikan dampak yang besar dalam sektor-sektor ekonomi Singapura, termasuk merugikan sektor bisnis yang sangat bergantung pada konsumsi domestik dan permintaan eksternal (CNBC, 2020a).

Kontraksi pertumbuhan ekonomi selama dua kuartal berturut-turut juga menandakan bahwa resesi ekonomi Singapura saat ini menjadi yang terburuk jika dibandingkan dengan krisis keuangan global tahun 2009. Hal ini juga dikarenakan ketergantungan Singapura di sektor perdagangan membuat perekonomian Singapura semakin terpuruk, akibat dari tidak adanya permintaan global dan lemahnya harga barang produksi Singapura (The Jakarta Post, 2020a).

Melalui pengalaman lalunya saat wabah SARS dan H1N1, respon Singapura terhadap Pandemi COVID-19 dinilai lebih cepat, tanggap, dan terkoordinasi. Sebab negara ini telah menyiapkan semacam rencana strategis apabila terdapat hal serupa. Meskipun demikian, masih terdapat hambatan yang dialami oleh Singapura dalam menghadapi ancaman Pandemi COVID-19 di sektor ekonomi yang tidak dapat dihindari. Dapat dilihat bahwa negara seperti Singapura ancaman resesi ekonomi tetap ada padahal persiapan sudah direncanakan sebaik mungkin dan sudah sangat responsif sekali di awal kasus pertama COVID-19. Tentu saja dengan kondisi ini dikhawatirkan akan ada efek domino bagi negara di ASEAN lainnya yang memiliki keadaan dan kecenderungan ekonomi mirip dengan Singapura (Abdullah \& Kim, 2020).

Berdasarkan data dan fakta di lapangan bahwa ancaman resesi ekonomi Singapura berasal dari tingkat bahaya Pandemi tersebut, yang menyebabkan timbul ketidakpastian pada berbagai sektor ekonomi negara. Contohnya saja COVID-19 membuat masyarakat lebih waswas dan mengutamakan menyimpan tabungan daripada membelanjakannya, membuat peredaran uang menjadi sedikit. Dengan demikian dapat dilihat bahwa Pandemi ini telah memberikan perubahan besar bagi kebijakan dan langkah pemerintah dalam menyikapinya. Hal ini menjadi penting mengingat dampak dari penurunan pertumbuhan ekonomi yang terjadi akan memberikan ancaman terhadap terjadinya resesi ekonomi. Aktivitas perdagangan internasional 
yang menurun beriringan dengan permintaan global memberikan dampak yang besar bagi Singapura. Di sektor pariwisata juga mengalami penurunan besar akibat tidak adanya wisatawan asing yang datang berlibur ke Singapura.

Dari sejumlah persoalan ekonomiyang dihadapi baik Indonesia, Filipina maupun Singapura, terlihat bahwa ketiga negara memiliki persoalan yang hampir sama dikarenakan aktivitas ekonomi yang belumberjalan optimal berakibatpada pertumbuhan ekonomi yang turun. Gangguan ekonomi yang terjadi akibat COVID-19 mengakibatkan sejumlah persoalan sosial dan ekonomi lainnya seperti peningkatan pengangguran, permasalahan distribusi pendapatan, konsumsi domestik yang mengalami penurunan sampai dengan gangguan terhadap sektor lainnya.

Dampak COVID-19 di ASEAN memiliki pengaruh langsung terhadap perekonomian setiap negara. Keberanekaragaman kondisi ASEAN menimbulkan masalah serius yang berbeda pada masing-masing negara. Misalnya saja permasalahan ekonomi karena COVID-19 di Singapura dan Indonesia pastilah berbeda, mengingat kondisi perekonomian yang tidak sama. Demikian pula dengan kebijakan tiap negara ASEAN dalam menangani masalah ini (Fauzi \& Paiman, 2020).

Dalam kuartal pertama tahun 2020 pertumbuhan regional ASEAN menyusut menjadi 0,5\% dimana angka tersebut terendah sejak 1967. Bahkan hingga Agustus 2020, peluang pemulihan ekonomi dan lapangan kerja tetap belum pasti. Meningkatnya hutang nasional, pembatasan perdagangan, dan rantai pasokan yang terganggu menyebabkan beban lebih bagi negara ASEAN. Perbedaan kecepatan dalam menanggulangi COVID-19 menyebabkan beberapa negara sudah mulai melonggarkan lockdown dan sebagian lagi belum. Seperti misalnya Singapura yang sudah membuka kembali bisnis negara sedangkan Indonesia dan Filipina masih berada di gelombang pertama COVID-19 (Djalante, et al., 2020).

Secara garis besar beberapa permasalahan ekonomi yang akan dihadapi negara ASEAN karena COVID-19. Dimulai dari perlambatan ekonomi yang berlanjut, apalagi bagi yang masih mengalami pertumbuhan negatif. Lalu meningkatnya pengangguran akibat dari PHK menyebabkan hubungan pasar tenaga kerja tertutup. Dengan demikian beresiko untuk membuat efek domino pada tiap negara ASEAN yang cukup besar (Chong, Li, \& Yip, 2020).

\section{PEMBAHASAN}

\section{Kebijakan Indonesia, Filipina, dan Singapura dalam Menyikapi Resesi Ekonomi}

Sehubungan dengan COVID-19, setiap negara mengambil langkah dalam menyikapi resesi ekonomi. Seperti misalnya di kawasan Eropa, sikap Uni Eropa (UE) dalam menyikapi COVID-19 sangat serius, dimana mereka saling mengkoordinasikan kebijakan dan tanggapan terkait Pandemi ini. Seluruh negara anggota UE sepakat untuk bekerjasama dalam menangani Pandemi COVID-19. Mereka sering melakukan pertemuan secara virtual untuk membahas langkah apa saja yang harus dilakukan, secara transparan. Hal ini bertujuan untuk mendukung pembaruan informasi mengenai perkembangan dari Pandemi COVID-19 di kawasan mereka (Goniewicz, et al., 2020).

Dalam menekan penyebaran virus COVID-19, baik negara maju maupun berkembang menerapkan kebijakan lockdown. Sehingga semua penerbangan internasional dibatasi dan untuk penerbangan domestik ditangguhkan sampai waktu yang belum dapat ditentukan. Dan juga melarang setiap wisatawan asing untuk berkunjung ke negara tujuan, namun bagi wisatawan yang sudah berada di negara tujuan harus melakukan karantina mandiri selama 14 hari. UNWTO juga menyebutkan bahwa kawasan Eropa, terutama Eropa Barat telah menutup 93\% destinasi pariwisata internasional di setiap wilayah perbatasannya, yang akan sangat berdampak pada perekonomian di kawasan Eropa Barat (Haryanto, 2020).

Dari adanya Pandemi COVID-19 ini, diperkiraan Uni Eropa akan mengalami kontraksi nilai mata uang Euro sebesar 10\% disamping dari upaya-upaya yang dilakukan untuk memberikan stimulus bagi perekonomian Uni Eropa, baik itu dalam bentuk kebijakan fiskal maupun moneter. Namun perlu dipahami kembali, perekonomian dari setiap negara anggota Uni Eropa tidak merata. Oleh karenanya, penetapan kebijakan fiskal dan moneter harus lebih diperketat agar perekonomian dapat terus bertumbuh dan berkelanjutan (Bergsen, 2020). COVID-19 merupakan hal yang baru terjadi di UE, membuat regional tersebut tetap harus beradaptasi. Setiap kebijakan yang diambil di dalam UE cukup terdesentralisasi, membuat semuanya harus dibicarakan dulu secara bersamaan dengan seluruh anggota. Terkadang di salah satu negara UE ada yang sudah sangat kacau akibat COVID-19, namun karena kebijakan yang 
dikeluarkan harus bersama-sama maka terpaksa harus menunggu. Hal ini menjadi salah satu akibat kasus di kawasan tersebut cukup tinggi, bahkan saat ini sudah masuk ke gelombang kedua (Kovac, Elkanawati, Gjikolli, \& Vardenberghe, 2020)

Kebijakan jangka pendek untuk mengatasi urgensi Pandemi COVID-19 tampaknya tidak akan menjadi opsi pilihan berkelanjutan jangka panjang. Meskipun memang kebijakan jangka pendek yang diambil lebih menyoroti permasalahan yang saat ini sedang terjadi. Permasalahan selama COVID-19 terjadi memang mendesak pemerintah untuk mengeluarkan kebijakan, agar dapat terselesaikan. Akan tetapi perlu dicermati bahwa satu permasalahan dapat menyebabkan permasalahan lain, sehingga rasanya kurang tepat apabila hanya kebijakan jangka pendek yang difokuskan. Kebijakan jangan panjang dan berkelanjutan juga perlu dipersiapkan (Ibn-Mohammed, et al., 2020).

Seperti halnya dengan yang terjadi di kawasan Eropa, berdasarkan data dan fakta yang telah diuraikan, sebagian negara ASEAN memasuki jurang resesi ekonomi dan sebagian lagi hampir. Maka dari itu untuk menyikapi resesi ekonomi terdapat beberapa kebijakan yang dikeluarkan oleh negara untuk menghadapi hal tersebut. Kebijakan dapat menjadi langkah pencegahan atau perbaikan dari pemerintah untuk menyelamatkan negaranya sebelum hal yang lebih parah terjadi. Termasuk juga dalam menyikapi resesi ekonomi yang diakibatkan oleh Pandemi COVID-19. Sebab ancaman resesi ekonomi benar-benar dirasakan oleh seluruh negara baik negara maju maupun berkembang. Berikut ini akan dijabarkan bagaimana kebijakan dari beberapa Indonesia, Filipina, dan Singapura dalam menyikapi resesi ekonomi.

Indonesia termasuk ke dalam negara yang sedang menuju dan berusaha untuk meminimalisir jatuhnya tingkat perekonomiannya yang dapat berujung pada resesi ekonomi. Dalam mencegah hal tersebut, Indonesia menerapkan kebijakan ekonomi untuk mencegah ketidakstabilan di sektor keuangan. Kebijakan ekonomi ini dilampirkan dalam Peraturan Pemerintah Pengganti UndangUndang Republik Indonesia No. 1 Tahun 2020 mengenai Kebijakan Keuangan Negara dan Stabilitas Sistem Keuangan dalam Penanganan Pandemi COVID-19 dan/atau Menghadapi Ancaman yang Membahayakan Perekonomian Nasional dan/atau Stabilitas Sistem Keuangan.
Di dalam peraturan tersebut, disebutkan bahwa pemerintah akan menggunakan APBN tahun 2020 untuk keperluan menangani Pandemi COVID-19. Peraturan pemerintah tersebut juga menyebutkan beberapa kebijakan dan kewenangan pemerintah yang meliputi; Mengubah pembatasan defisit anggaran sebesar 3\% dari PDB sampai dengan tahun anggaran 2022; Mengalokasikan anggaran dari Sisa Anggaran Lebih, seperti dana abadi pendidikan, khususnya dana negara, Badan Layanan Umum atau dana hasil divestasi BUMN; Menerbitkan surat utang negara yang dapat dibeli oleh Bank Indonesia, BUMN dan perusahaan ritel. Dan total keseluruhan APBN 2020 sebesar Rp 405,1 triliun, yang juga dialokasikan ke beberapa sektor seperti kesehatan Rp 75 triliun, pengaman sosial Rp 110 triliun, dan insentif perpajakan dan stimulus Kredit Usaha Rakyat atau UMKM sebesar Rp 70,1 triliun (Dentons HPRP, 2020).

Indonesia juga menerapkan kebijakan fiskal dan moneter yang dinyatakan oleh Kementerian Keuangan. Kebijakan fiskal yang dicanangkan oleh kementerian keuangan berupa mengalokasikan ulang dana APBN Rp 62,3 Triliun yang diambil dari beberapa anggaran negara seperti belanja non operasional negara, perjalanan dinas, perlindungan sosial, penanganan COVID-19 dan insentif dunia usaha. Selain itu Kementerian Keuangan juga menambahkan stimulus pajak karyawan dan dunia usaha yang menjadi tanggungan pemerintah seperti pajak penghasilan, pengurangan angsuran $\mathrm{PPh}$, dan pembebasan pajak penghasilan impor. Sedangkan kebijakan moneter yang diterapkan oleh Kementerian Keuangan dilakukan untuk menjaga stabilitas nilai tukar rupiah, mencegah terjadinya inflasi, dan memberikan stimulus untuk dunia usaha seperti UMKM. Kebijakan moneter yang diterapkan harus sejalan dengan kebijakan fiskal yang diterapkan oleh Kementerian Keuangan agar hal-hal tersebut dapat terealisasikan dan menjaga stabilitas perekonomian nasional (Direktorat Jenderal Kekayaan Negara Kementerian Keuangan, 2020).

Usaha Kecil dan Menengah (UMKM) menjadi salah satu pihak yang terpukul keras akibat COVID-19, seperti yang ada di Indonesia. Padahal UMKM sangat berjasa bagi perekonomian Indonesia mulai dari menambah PDB, menyediakan lapangan pekerjaan, membantu kegiatan ekspor dan investasi. Hal ini membuat pemerintah Indonesia mengeluarkan kebijakan untuk membantu UMKM agar dapat 
bangkit kembali di tengah COVID-19. Kebijakan pemerintah Indonesia terkait UMKM yaitu fokus untuk memberikan perkenalan teknologi digital pada mereka dalam kegiatan berbisnis, sehingga tidak harus mengandalkan kegiatan bertemu secara langsung. Dapat dikatakan bahwa hal ini sekaligus sebagai persiapan sebelum masuk pada industri 4.0 (Thaha, 2020).

Pemerintah Indonesia mengambil beberapa langkah kebijakan untuk menyikapi persoalan ekonomi maupun sosial lainnya. Beberapa kebijakan stimulus juga diambil untuk meningkatkan kembali aktivitas perekonomian. Kebijakan moneter dan fiskal diambil untuk mencegah persoalan ekonomi yang lebih berat. Harmonisasi kebijakan fiskal maupun moneter dilakukan untuk meminimalisir ancaman resesi ekonomi. Dengan demikian pada kuartal III 2020, diharapkan pertumbuhan ekonomi Indonesia dapat mengalami peningkatan meskipun hal tersebut belum dapat dipastikan akibat dari Pandemi COVID-19 yang belum juga menemukan titik terang hingga saat ini. Maka berbagai kemungkinan harus siap dihadapi oleh Indonesia.

Di samping dua kebijakan tersebut, pemerintah Indonesia juga menerapkan suatu program yang termasuk ke dalam strategi kebijakan ekonomi Indonesia dalam menghadapi COVID-19, yaitu Program Pemulihan Ekonomi Nasional (PEN) yang dicanangkan oleh Presiden Joko Widodo dan diketuai oleh Menko Perekonomian Airlangga Hartanto. Dalam implementasinya, program ini memberikan suntikan dana Rp 14,1 triliun ke empat BUMN untuk meningkatkan kapasitas dan operasi yang dilakukan selama COVID-19. Selain itu pemberian insentif pajak bagi dunia usaha senilai Rp 123,01 triliun juga tertuang di dalam program PEN. Insentif pajak tersebut didapatkan dari potongan pajak impor bahan baku, pajak penghasilan, dan retribusi awal pajak pertambahan nilai. Beberapa program dan kebijakan yang dicanangkan oleh Indonesia, dilakukan guna menjaga dan menopang perekonomian Indonesia dari ancaman resesi ekonomi (AHK Indonesien, 2020).

Cepat atau lambatnya proses pemulihan ekonomi Indonesia melalui kebijakan dan program yang dicanangkan, juga bergantung pada cepat lambatnya proses pemulihan kondisi kesehatan masyarakat Indonesia pasca Pandemi COVID-19. Sehingga kebijakan atau program yang dijalankan, juga harus sejalan dengan kondisi kesehatan masyarakat Indonesia yang juga membaik dari waktu ke waktu. Dengan begitu kebijakan dan program yang diterapkan dapat memiliki dampak yang efektif bagi proses pemulihan perekonomian Indonesia dan juga sekaligus bersiap dalam menghadapi ancaman resesi ekonomi yang tidak dapat diprediksi (Wardhana, 2020). Oleh karena itu, serangkaian kebijakan yang diambil tentu saja juga dibarengi dengan penurunan kasus positif COVID-19. Hal ini menjadi penting karena apabila program pemulihan ekonomi tidak dibarengi dengan program kesehatan yang optimal dalam menurunkan kasus COVID-19, maka kebijakan ekonomi tersebut tidak akan optimal. Kondisi ini bisa terjdi apabila peningkatan kasus semakin tinggi tidak menutup kemungkinan aktivitas ekonomi juga akan mengalami gangguan seperti di awal-awal kasus ini muncul. Program pemerintah, kerja sama masyarakat menjadi sangat penting dilakukan untuk merealisasikan kebijakan dapat berjalan dengan baik.

Di sisi lain, meningkatnya jumlah masyarakat Filipina yang terinfeksi COVID-19 memberikan dampak yang cukup besar bagi perekonomian Filipina, sehingga membuat perekonomian Filipina jatuh hingga 16,5 persen terhitung dari PDB di kuartal kedua. Hal ini dikarenakan fokus pemerintah Filipina yang lebih berfokus pada pembatasan kegiatan masyarakat untuk menekan penyebaran COVID-19. Hal tersebut membuat Filipina mengalami resesi ekonomi untuk pertama kalinya dalam tiga dekade terakhir. Mengutip pernyataan Presiden Filipina Rodrigo Duterte bahwa sejak diberlakukannya lockdown Filipina tidak lagi memiliki uang, negara sudah tidak bisa lagi memberikan masyarakat makanan dan uang. Maka dari itu, pemerintah Filipina menyikapi ancaman resesi ekonomi ini melalui suatu kebijakan agar perekonomian dapat terselamatkan (The Jakarta Post, 2020b).

Presiden Duterte mengeluarkan kebijakan paket stimulus ekonomi sebesar 531 juta dollar AS pada tanggal 16 Maret 2020. Paket kebijakan untuk mensubsidi gaji pegawai pemerintah dan dukungan terhadap industri pariwisata serta jaminan sosial. Paket kebijakan lanjutannya, yaitu kebijakan "state of calamity", kebijakan ini memungkinkan pemerintah pusat dan daerah untuk segera mencairkan dana untuk proses pemulihan ekonominya. Sepanjang bulan MaretApril, pemerintah juga menyetujui program perlindungan sosial untuk kota dan kotamadya, 
dana ini berasal dari pendapat internal kota dan kotamadya (Muhibat, 2020).

Dalam menyikapi resesi ekonomi yang terjadi, Filipina menerapkan kebijakan fiskal dan moneter yang diharapkan dapat menekan persentase resesi ekonomi. Kebijakan fiskal yang diambil oleh Filipina dalam menghadapi ancaman resesi ekonomi adalah melaksanakan Social Amelioration Program (SAP). Kebijakan ini bertujuan untuk memberi bantuan finansial pada setiap rumah tangga sebesar 5.000-8.000 peso Filipina. Tentunya bantuan tersebut ditujukan agar masyarakat dapat memenuhi kebutuhan sehariharinya selama masa Pandemi ini. SAP sekaligus menjadi paket stimulus bagi masyarakat untuk memulihkan kembali perekonomian negara.

Di samping itu, pemerintah juga mengeluarkan kebijakan pembebasan pajak penghasilan bagi masyarakat menengah kebawah baik karyawan swasta maupun publik untuk mengatasi persoalan masyarakat yang pendapatannya berkurang akibat PHK atau pemotongan gaji, namun demikian, bagi karyawan berpenghasilan tinggi tetap harus membayar pajak penghasilan, agar tetap ada pendapatan bagi negara. Selain itu, pemerintah mengeluarkan kebijakan untuk menangguhkan sementara Pajak Pertambahan Nilai (PPN). Barang yang termasuk dalam PPN adalah kebutuhan pokok rumah tangga dan obatobatan. Maka dapat dikatakan bahwa melalui kebijakan fiskal ini, pemerintah Filipina fokus untuk menangani permasalahan yang ada pada masyarakatnya (Juan, 2020).

Sementara untuk kebijakan moneter, berdasarkan pernyataan dari Gubernur Filipina Francisco Dakila Jr., BSP atau The Bangko Sentral ng Pilipina's telah melakukan beberapa tindakan moneter yaitu dengan melakukan pemotongan suku bunga off-cycle yang bertujuan untuk mengalokasikan beberapa pinjaman dari beberapa sektor ke sektor yang lebih rentan terhadap Pandemi COVID-19. Pemotongan suku bunga off-cycle ini juga akan diberikan kepada beberapa UMKM masyarakat Filipina yang sedang mengalami masa sulit ekonomi. Langkah-langkah ekonomi yang diambil oleh Dewan Moneter Filipina ini akan terus dilakukan hingga perekonomian Filipina mencapai tingkat pemulihan ekonomi yang ditetapkan, sekaligus juga memperkuat langkah kebijakan ekonomi fiskal yang telah di inisiasikan oleh pemerintah nasional (Bangko Sentral NG Pilipinas, 2020). Kedepannya, BSP akan terus mendukung dan membantu lembaga-lembaga pemerintah lainnya dalam mencukupi kebutuhan-kebutuhan ekonomi seperti dana ataupun pinjaman, serta akan siap sedia untuk menggunakan instrumen-instrumen moneternya dalam menerapkan setiap langkah regulasi untuk menjaga stabilitas keuangan negara dari ancaman resesi ekonomi (DeutschPhilippinische Industrie-und Handleskammer, 2020).

Salah satu hal yang mendorong pemerintah Filipina lebih tanggap dalam menangani COVID-19 ialah karena berdasarkan fakta bahwa saat ini jumlah masyarakat yang produktif sebesar 51\%. Semakin bertambahnya tahun angka masyarakat produktif akan semakin menurun, hal ini membuat pemerintah Filipina lebih terdorong untuk menyikapi COVID-19 secara serius. Mengapa demikian? Karena jika dari sekarang sudah banyak masyarakat yang meninggal karena COVID-19 maka kategori masyarakat produktif dapat menurun dan berpengaruh terhadap perekonomian negara (Vallejo Jr \& Ong, 2020).

Langkah yang diambil dalam menyikapi resesi ekonomi juga dilakukan oleh Singapura sebagai negara yang telah mengalami resesi ekonomi akibat imbas dari COVID-19. Singapura juga mengambil beberapa langkah kebijakan untuk mengatasi resesi yang terjadi. Terkait dengan persoalan ekonomi dan masalah kesehatan, Singapura merupakan salah satu negara yang dapat memulihkan perekonomian negaranya saat terjadi wabah SARS dan H1NI. Saat itu Singapura dapat dapat memulihkan ekonominya dalam waktu dua tahun saja. Begitupun juga dengan Pandemi COVID-19, terdapat kebijakan yang telah diupayakan oleh pemerintah Singapura dalam menyikapi resesi ekonomi. Kebijakan pemerintah Singapura dalam menangani kasus COVID-19 terkait kesehatan dapat dikatakan cukup berhasil, terbukti dari tingkat kematian yang rendah (Kimura, Thangavelu, Narjoko, \& Findlay, 2020).

Kebijakan Singapura dalam menghadapi resesi ekonomi dapat dibagi menjadi kebijakan fiskal dan kebijakan moneter. Pada kebijakan fiskal, terdapat empat paket kebijakan yang dikeluarkan oleh pemerintah. Paket pertama diumumkan oleh Menteri Keuangan pada 18 Februari 2020. Paket pertama ditujukan untuk mengurangi dampak COVID-19 kepada para pekerja dan dunia usaha sebesar 4 miliar dolar Singapura. Jumlah uang tersebut dibagi rata kepada pekerja dan dunia usaha untuk memberikan dukungan 
bagi mereka. Paket kedua diumumkan pada 26 Maret 2020, dengan anggaran sebanyak 48,4 miliar dolar Singapura. Anggaran ini ditujukan untuk memberikan dukungan pada rumah tangga, membantu agar pekerja tetap dapat bekerja, dan menyediakan dukungan untuk bisnis. Beberapa sektor yang terpukul langsung karena COVID-19 seperti transportasi, pariwisata, dan penerbangan diberikan bantuan berupa langkahlangkah untuk menstabilkan perekonomian kembali. Paket ketiga diumumkan pada 6 April 2020. Saat paket ketiga diumumkan, bertepatan dengan mulai diberlakukannya lockdown di Singapura yang banyak memberikan dampak ekonomi bagi masyarakat dan dunia usaha. Maka untuk meredam dampak tersebut, pemerintah mengeluarkan undang-undang bantuan tambahan sementara hingga lockdown mulai dilonggarkan. Bantuan tersebut sebanyak 5,1 miliar dolar Singapura (KPMG International, 2020).

Paket keempat diumumkan pada 26 Mei 2020 dengan anggaran sebesar 33 miliar dolar Singapura. Isi dari paket keempat tersebut antara lain: dukungan finansial bagi sektor usaha yang tidak dapat melanjutkan operasionalnya pasca lockdown, atau bagi sektor usaha yang terpukul langsung COVID-19. Selanjutnya memberikan bantuan dan keringanan bagi usaha kecil dan menengah. Berikutnya memberikan keringanan dan potongan retribusi bagi pekerja asing yang bekerja di sektor industri tertentu seperti kelautan, konstruksi, dan lepas pantai. Terakhir, menambah lapangan pekerjaan sebanyak 40.000 baik pada sektor publik maupun swasta (CNBC, 2020b).

Melalui kebijakan paket stabilisasi dan dukungan, dapat dilihat bahwa kebijakan Singapura dalam menghadapi resesi ekonomi ialah fokus pada memberikan bantuan terlebih dahulu kepada masyarakatnya. Terlebih, masyarakat Singapura berjumlah sedikit sehingga akan lebih mudah bagi pemerintah untuk memberikan bantuan. Tak hanya itu saja, beberapa dunia usaha yang terkena COVID-19 juga diberikan bantuan dari pemerintah Singapura sebab Singapura sangat bergantung kepada perdagangan internasional mulai dari ekspor, impor, dan perdagangan jasa.

Inti dari kebijakan fiskal Singapura dalam menyikapi resesi ekonomi ialah bagaimana mereka mengalokasikan cadangan negaranya yang besar agar dapat membantu perekonomian negara serta dapat diberikan kepada seluruh masyarakat dan sektor bisnis secara merata. Lebih spesifik lagi bahwa kebijakan fiskal dapat membantu negara dalam mengatasi COVID-19 melalui pengecekan dan perawatan gratis bagi masyarakat. Kebijakan fiskal ini sebenarnya sudah dipikirkan secara matang persiapannya pasca wabah SARS di tahun 2003 agar Singapura dapat lebih siap lagi menghadapi krisis semacam itu (Woo, 2020).

Selain itu Perdana Menteri Singapura, Lee Hsien Loong menyatakan bahwa beberapa sektor industri Singapura dibuka secara bergiliran pasca dilonggarkannya lockdown pada Juni. Namun sektor yang melibatkan keramaian dan melibatkan banyak kontak seperti misalnya pariwisata dan penerbangan akan dibuka lebih lama, di saat keadaan sudah memungkinkan. Melalui kebijakan pembukaan beberapa sektor ini, diharapkan dapat membantu pertumbuhan ekonomi Singapura yang mengalami resesi serta memberikan masukkan kembali bagi Singapura yang dapat dialokasikan sebagai cadangan negara yang sudah banyak digunakan selama Pandemi ini berlangsung (The Straits Times, 2020).

Di sisi lain kebijakan moneter Singapura dalam menghadapi resesi ekonomi dialokasikan pada tiga poin. Pertama, menurunkan tingkat apresiasi dolar Singapura menjadi 0\% agar nilai tukar dapat tetap stabil terlebih bagi nilai tukar yang rendah. Kebijakan pertama ini bersifat akomodatif dan suportif, mengingat kebijakan moneter negara ini terletak pada nilai tukar dolar Singapura. Kedua, memprioritaskan kelancaran fungsi pasar pendanaan jangka pendek agar tetap mampu menyediakan likuiditas. Saat adanya Pandemi COVID-19, secara global likuiditas mendapat harga yang tinggi. Dengan demikian pemerintah Singapura mengupayakan agar fungsi pasar pendanaan tetap stabil sehingga tidak berbahaya bagi negara. Ketiga, bersama dengan lembaga keuangan memberikan dukungan kredit untuk individu dan UKM. Dalam hal ini, pemerintah Singapura dan lembaga keuangannya bersamasama merumuskan dukungan. Bagi individu, lembaga keuangan sepakat untuk memberi moratorium berupa pinjaman hingga akhir tahun. Sedangkan bagi UKM dapat ditangguhkan dulu pelunasan pokoknya apabila jaminannya baik (Monetary Authority Of Singapore, 2020).

Berdasarkan penjabaran di atas, terlihat bahwa Singapura menerapkan kebijakan moneter untuk menunjang pertumbuhan ekonomi yang telah mengalami resesi. Terlebih Singapura bertumpu pada nilai tukarnya, maka pemerintah harus berupaya agar dolar Singapura dapat tetap stabil. 
Itulah mengapa kebijakan moneter dilakukan agar pertumbuhan ekonomi dapat meningkat, neraca pembayaran tetap seimbang, dan tetap pada kestabilan yang diharapkan. Apalagi di tengah ketidakpastian ekonomi saat ini, membuat keadaan ekonomi kembali membaik ataupun bertambah buruk.

World Bank pernah menyatakan bahwa negara yang bergantung pada perdagangan internasional dan sektor pariwisata, di prediksi akan mengalami resesi ekonomi yang lebih berkepanjangan daripada yang lainnya. Dimana Singapura merupakan salah satu negara yang bergantung pada kedua hal tersebut, maka jika di prediksi berdasarkan World Bank bahwa Singapura akan mengalami resesi ekonomi yang berkepanjangan. Pada kenyataannya pemerintah Singapura dalam menangani COVID-19 lebih memfokuskan dulu untuk membenahi kesehatan secara sigap. Hingga barulah membenahi perekonomian, meskipun pada akhirnya mengalami resesi juga tetapi dalam segi kesehatan mereka cukup baik (Hennida, 2020).

Selama Pandemi COVID-19 baik Indonesia, Filipina, dan Singapura telah bertemu secara virtual dalam kerangka ASEAN terkait pengambilan kebijakan tingkat kawasan. Di dalam pertemuan tersebut terdapat beberapa saran untuk penanganan COVID-19 pada aspek ekonomi, kesehatan, dan keamanan. Salah satunya ialah terbentuknya ASEAN COVID-19 Respond Fund dimaksudkan untuk mengatasi permasalahan kurangnya peralatan medis akibat COVID-19. Sehingga apabila persediaan peralatan medis salah satu negara ASEAN menipis, maka dapat dibantu melalui ASEAN COVID-19 Respond Fund (Hariyadi, 2020).

\section{SIMPULAN}

Kebijakan yang diambil oleh Indonesia, Filipina, dan Singapura dalam mengatasi perluasan COVID-19 telah menimbulkan permasalahan yang kompleks seperti penurunan aktivitas ekonomi yang diwarnai dengan penurunan konsumsi domestik, kegiatan perdagangan, pariwisata, maupun peningkatan pengangguran dan penurunan distribusi pendapatan. Aktivitas ekonomi yang belum pulih sepenuhnya setelah pelonggaran kebijakan karantina ataupun pembatasan mobilitas orang belum bisa mendorong peningkatan pertumbuhan ekonomi yang mengalami penurunan sejak kasus COVID-19 muncul di tiga negara tersebut.
Secara umum, indikator ekonomi di tiga negara ini diwarnai dengan kontraksi PDB yang cukup besar.

Menyikapi ancaman resesi ekonomi ataupun mencegah kondisi resesi ekonomi lebih dalam, kebijakan seperti fiskal dan moneter diambil untuk memberikan dukungan terhadap peningkatan kegiatan ekonomi yang dapat berkontribusi pada pertumbuhan ekonomi. Dukungan terhadap sektor-sektor yang terdampak menjadi salah satu prioritas dari setiap pemerintah untuk menghidupkan kembali aktivitas ekonomi, seperti UMKM maupun kelompok bisnis lainnya. Di samping itu, kestabilan nilai mata uang juga menjadi fokus dari kebijakan moneter di setiap negara. Melalui langkah-langkah kebijakan yang diambil tersebut diharapkan pemulihan ekonomi dapat terealisasi dengan baik. Namun demikian, pemulihan ekonomi pada masa COVID-19 juga harus sejalan dengan upaya untuk mengurangi tingkat perluasan kasus COVID-19 untuk mencegah terjadinya krisis kesehatan lebih lanjut. Dengan demikian dapat dilihat bahwa persoalan resesi ekonomi pada masa COVID-19 lebih kompleks.

\section{PENGHARGAAN}

Ucapan terima kasih disampaikan kepada LPPM UPN Veteran Jakarta yang telah memberikan dukungan terhadap pelaksanaan penelitian mandiri yang sudah dilakukan oleh tim peneliti.

\section{DAFTAR PUSTAKA}

Abdullah, W. J., \& Kim, S. (2020, Juli 15). Singapore's Responses to the COVID-19 Outbreak: A Critical Assessment. SAGE Journals.

AHK Indonesien. (2020, September 3). COVID-19 Developments In Indonesia. Retrieved September 4, 2020, from AHK Indonesien: https:// indonesien.ahk.de/en/infocenter/news/newsdetails/COVID-19-developments-in-indonesia.

ASEAN REPORT. (2020, Agustus 5). Risk Assessment for International Dissemination of COVID-19 to the ASEAN Region ASEAN Biodiaspora Virtual Center (ABVC. Retrieved Agustus 20, 2020, from asean.org: https:// asean.org/storage/2020/02/COVID-19 Reportof-ASEAN-BioDias pora-Regional-VirtualCenter 5August2020.pdf.

Bangko Sentral NG Pilipinas. (2020, April 16). Monetary Board Cuts Policy Rate by 50 
Basis Points, Approves Package of Measures to Support MSMEs. Retrieved September 9, 2020, from Bangko Sentral NG Pilipinas: http://www. bsp.gov.ph/publications/media.asp?id=5358.

Barua, S. (2020). Understanding Coronanomics: The Economic Implications of the Coronavirus (COVID-19) Pandemic. Social Science Research Network, $X, 5$.

Bergsen, P. (2020). A New Political Economy for Europe post-COVID-19. SAGE Publications Journals, XIX(2), 132-133.

Boyce, C. J., Delaney, L., \& Wood, A. M. (2018, Agustus 29). The Great Recession and subjective well-being: How did the life satisfaction of people living in the United Kingdom change following the financial crisis? PLoS One, 13(8).

Chong, T. T., Li, X., \& Yip, C. (2020). The Impact of COVID-19 on ASEAN. Taylor\& Francis Online Journals, 19.

Classens, S., \& Kose, M. A. (2020, Februari 24). Recessions: When Bad Times Prevail. Retrieved Agustus 25, 2020, from imf.org: https:// www.imf.org/external/pubs/ft/fandd/basics/ recess.htm

CNBC. (2020a, Juli 13). Singapore Enters Recession After Economy Shrinks More Than 40\% Quarter On Quarter. Retrieved September 3, 2020, from CNBC. https://www.cnbc. com/2020/07/14/singapores-q2-advanced-gdpestimates-economy-contracts-12point6percentyear-over-year.html.

CNBC. (2020b, Mei 26). Singapore Plans $\$ 23.2$ Billion Fourth Stimulus Package To Support Coronavirus-Hit Economy. Retrieved September 3, 2020, from CNBC. https://www. cnbc.com/2020/05/26/singapore-plans-fourthstimulus-package-for-coronavirus-hit-economy. html.

CNBC Indonesia. (2020, September 2). Seram, Korban Jiwa Akibat Corona di RI Terbanyak se-ASEAN. Retrieved September 6, 2020, from cnbc.com. https://www.cnbcindonesia.com/ news/20200902011956-4-183716/seram-korbanjiwa-akibat-corona-di-ri-terbanyak-se-asean.

CNBC Indonesia. (2020b, Juli 14). Fakta Singapura Resmi Resesi, Ini Bukan yang Pertama! Retrieved September 1, 2020, from CNBC Indonesia. https://www.cnbcindonesia. com/news/20200714131045-4-172547/faktasingapura-resmi-resesi-ini-bukan-yang-pertama.

CNN Indonesia. (2020, Agustus 25). Sri Mulyani Ungkap Kemungkinan Besar Indonesia
Masuk Resesi. Retrieved September 1, 2020, from cnnindonesia.com. https://www.cnnindonesia. com/ekonomi/20200825140120-532-539043/srimulyani-ungkap-kemungkinan-besar-indonesiamasuk-resesi.

Dentons HPRP. (2020, April 14). Strategy for COVID-19 Pandemic in Indonesia: Forwardlooking in National Economic Stability. Retrieved September 4, 2020, from Dentons HPRP. https://dentons.hprplawyers.com/en/insights/ articles/2020/april/14/strategy-for-COVID-19pandemic-in-indonesia-forward-looking-innational-economic-stability.

Deutsch-Philippinische Industrie-und Handleskammer. (2020, May 5). Philippine Central Bank's response to COVID-19. Retrieved September 9, 2020, from DeutschPhilippinische Industrie-und Handleskammer: https://philippinen.ahk.de/news/news-details/ philippine-central-banks-response-toCOVID-19.

Direktorat Jenderal Kekayaan Negara Kementerian Keuangan. (2020, April 1). Kebijakan Fiskal dan Moneter Menghadapi Dampak COVID-19. Retrieved September 4, 2020, from Direktorat Jenderal Kekayaan Negara Kementerian Keuangan. https://www.djkn. kemenkeu.go.id/artikel/baca/13017/KebijakanFiskal-dan-Moneter-Mengadapi-DampakCOVID-19.html.

Djalante, R., Nurhidayah, L., Minh, H. V., Phuong, N. T., Mahendradhata, Y., Trias, A., . . . Miller, M. A. (2020). COVID-19 and ASEAN Responses: Comparative Policy Analysis. Science Direct, XIII, 2.

Fauzi, M. A., \& Paiman, N. (2020). COVID-19 Pandemic in Southeast Asia: Intervention and Mitigation Efforts. Asian Education and Development Studies, IX(3), 2-3.

Goniewicz, K., Manesh, A. K., Hertelendy, A. J., Goniewicz, M., Naylor, K., \& Burkle Jr., F. M. (2020). Current Response and Management Decisions of the European Union to the COVID-19 Outbreak: A Review. Multidisciplinary Digital Publishing Institute Journal, XXII(9), 3.

Hariyadi, R. P. (2020). Singapura dan ASEAN: Analisis Relasi Negara dan Institusi Kawasan di Tengah Pandemi COVID-19. Jurnal Dinamika Global, V(2), 308-309.

Haryanto, T. (2020). Editorial: COVID-19 Pandemic and International Tourism Demand. Journal of Developing Countries, V(1), 2-3. 
Hennida, C. (2020). Keberhasilan Penanganan COVID-19 di Singapura: Kasus Klaster Pekerja Migran dan Resesi Ekonomi. e-Journal Universitas Airlangga, XXIV(2), 249-252.

Ibn-Mohammed, T., Mustapha, K. B., Godsell, J., Adamu, Z., Babatunde, K. A., Akintade, D. D., . . . Koh, S. C. (2020). A Critical Analysis of the Impacts of COVID-19 on the Global Economy and Ecosystems and Opportunities for Circular Economy Strategies. National Center for Biotechnology Information, 18.

Juan, D. M. (2020, April 13). Economic Relief in the Time of COVID-19: Rationale, Mechanics, Costing, and Prospective Impact of Temporary Value-Added Tax (VAT) Suspension and Income Tax Waiver for the Poor and the Middle Class in the Philippines. Retrieved Agustus 25, 2020, from SSRN: https://papers.ssrn.com/sol3/papers. cfm?abstract_id=3571402.

Kim, S., Koh, K., \& Zhang, X. (2020,Agustus 25). Short-term Impact of COVID-19 on Consumption Spending and Its Underlying Mechanisms: Evidence from Singapore. SSRN Coronavirus and Infectious Disease Research eJournal.

Kimura, F., Thangavelu, S. M., Narjoko, D., \& Findlay, C. (2020, Juni 9). Pandemic (COVID-19) Policy, Regional Cooperation, and the Emerging Global Production Network. Asian Economic Journal.

Kose, M. A., Sugawara, N., \& Terrones, M. E. (2020, Maret). Global Recessions Policy Research Working Paper 9172. Retrieved Agustus 20, 2020, from worldbank.org. http://documents1.worldbank.org/curated/ en/185391583249079464/pdf/GlobalRecessions.pdf

Kovac, M., Elkanawati, A., Gjikolli, V., \& Vardenberghe, A.-S. (2020). The COVID-19 Pandemic: Collective Action and European Public Policy Under Stress. Central European Journal of Public Policy, XIV(2), 55.

KPMG International. (2020, Juni 17). Government And Institution Measures In Response To COVID-19. Retrieved September 3, 2020, from Singapore. https://home.kpmg/xx/en/home/ insights/2020/04/singapore-government-andinstitution-measures-in-response-to-COVID.html.

Mahatma, C. (2020, Agustus 4). Potret Pandemi COVID-19 di ASEAN. Retrieved September 6, 2020, from kompaspedia.kompas. id: https://kompaspedia.kompas.id/baca/paparantopik/potret-pandemi-COVID-19-di-asean.
Medcom.id. (2020, Agustus 3). 4 Negara Resesi Akibat COVID-19, Bagaimana Indonesia? Retrieved Agustus 25, 2020, from medcom. id: https://www.medcom.id/ekonomi/makro/ VNx4RJgN-4-negara-resesi-akibat-COVID-19bagaimana-indonesia.

Monetary Authority Of Singapore. (2020, Juni 11). "The COVID-19 Crisis: Risks and Policy Responses" - Transcript of "The Big Questions" - Central Banker Series Podcast by Mr Ravi Menon, Managing Director, Monetary Authority of Singapore, with Tim Adams, President and CEO, Institute of International Finance, on 28 May 2020. Retrieved September 3, 2020, from Monetary Authority Of Singapore: https://www. mas.gov.sg/news/speeches/2020/the-COVID-19crisis-risks-and-policy-responses.

Muhibat, S. F. (2020, April 16). COVID-19 In Southeast Asia: 10 Countries. Retrieved Agustus 5, 2020, from CSIS Commentaries DMRU-051EN: https://www.csis.or.id/publications/COVID19-in-southeast-asia-10-countries-10-responses/.

Nasution, D. A., Erlina, E., \& Muda, I. (2020). Dampak Pandemi COVID-19 terhadap Perekonomian Indonesia. Jurnal Benefita Ekonomi Pembangunan, Manajemen Bisnis, dan Akuntansi, V(2), 213.

Nicola, M., Alsafi, Z., Sohrabi, C., Al-Jabir, A., Al-Jabir, A., Losifidis, C., . . . Agha, R. (2020). The Socio-economic implications of the coronavirus pandemic (COVID-19): A review. International Journal of Surgery, 185-193.

Ozili, P. K., \& Arun, T. (2020). Spillover of COVID-19: Impact on the Global Economy. Social Science Research Network, X, 3.

Pharmaceutical-technology.com. (2020). Coronavirus in Phillipines: The COVID-19 Risk, Impact, and Measures. Retrieved Agustus 20, 2020, from Pharmaceutical-technology. com: https://www.pharmaceutical-technology. $\mathrm{com} /$ features/coronavirus-affected-countriesphilippines-measures-impact-tourismeconomy/.

Thaha, A. F. (2020). Dampak COVID-19 terhadap UMKM di Indonesia. Jurnal Universitas Muslim Maros, II(1), 151-152.

The Jakarta Post. (2020a, Agustus 11). VirusHit Singapore's Q2 Recession Deeper Than Estimated. Retrieved September 3, 2020, from The Jakarta Post. https://www.thejakartapost. com/news/2020/08/11/virus-hit-singapores-q2recession-deeper-than-estimated-.html. 
The Jakarta Post. (2020b, Agustus 6). Virus-Hit Philippine Economy Plunges Into Recession. Retrieved Agutus 25, 2020, from The Jakarta Post. https://www.thejakartapost.com/ news/2020/08/06/virus-hit-philippine-economyplunges-into-recession--.html.

The Straits Times. (2020, April 30). S'pore Economy To Open Up 'Step By Step' After COVID-19 Circuit Breaker, Some Sectors To Restart Earlier Than Others: PM Lee. Retrieved September 3, 2020, from The Straits Times: https://www.straitstimes.com/singapore/sporeeconomy-to-open-up-step-by-step-after-COVID19-circuit-breaker-some-sectors-to.

Think.ing.com. (2020, Juli 20). Phillipines: Entering A Lower Growth Trajectory? Retrieved Agustus 28, 2020, from Think.ing.com: https:// think.ing.com/articles/philippines-entering-thedirty-1-recovery-lower-growth-gdp-trajectoryCOVID-19-lockdowns-peso-fx-currency-fiscal.

TribunNews. (2020, April 1). UPDATE Corona Global, 1 April 2020: Kasus COVID-19 Indonesia Urutan ke-36 Setelah Thailand. Retrieved September 6, 2020, from tribunnews.com. https://www.tribunnews.com/ corona/2020/04/01/update-corona-global-1 april-2020-kasus-COVID-19-indonesia-urutanke-36-setelah-thailand?page $=4$.
United Nations. (2020, Mei 1). The Pandemic Crisis Will Worsen Global Inequality. Monthly Briefing on The World Economic Situation And Prospects.

United Nations Development Program. (1994). Human Development Report. UNDP.

Vallejo Jr, B. M., \& Ong, R. A. (2020). Policy Responses and Government Science Advice. Science Direct, VII, 1-2.

Wardhana, D. (2020, Juni). Kajian Kebijakan dan Arah Riset Pasca COVID-19. The Indonesian Journal of Development Planning.

Woo, J. (2020). Policy Capacity and Singapore's Response To COVID-19 Pandemic. Policy and Society.

World Bank. (2020, Juni 8). The Global Economic Outlook During the COVID-19 Pandemic: A Changed World. Retrieved Agustus 28, 2020, from worldbank.org. https://www. worldbank.org/en/news/feature/2020/06/08/theglobal-economic-outlook-during-the-COVID19-pandemic-a-changed-world.

World Socialist Website. (2020, Agustus 11). Indonesian economy contracts for first time in over two decades. Retrieved Agustus 30, 2020, from wsws.org: https://www.wsws.org/en/ articles/2020/08/11/indo-a11.html. 